\title{
Social Capital in Poverty Reduction: A Systematic Literature Review
}

\author{
Adi Syahid M.A ${ }^{a}$, J. Faathirah ${ }^{\mathrm{b}}$ and Tuan Muhammad Zukri bin Tuan Sembok \\ A \\ Department of Social Sciences, Centre for General Studies and Co-curricular, Universiti Tun Hussein Onn, Batu Pahat, Johor, \\ Malaysia. \\ ${ }^{\mathbf{b}}$ Freelance Researcher \\ CInstitute of Poverty Research and Management, Universiti Malaysia Kelantan
}

Article History: Received: 11 January 2021; Accepted: 27 February 2021; Published online: 5 April 2021

\begin{abstract}
Poverty reduction is a global issue and it is often associated with economic-based solutions. While most of the times, poverty solution is discussed through economic variables, more recent studies nowadays have started to suggest social capital as the alternative solution to poverty reduction. The present article sets out to analyse the existing literature on social capital and how it can affect poverty level of a household. PRISMA Statement (Preferred Reporting Items for Systematic reviews and Meta-Analyses) as a review method, a systematic review was done on 10 databases where it had identified 472 relevant studies. Through the review, social capital was commonly measured by several themes known as social participation, social cohesion, social network, trust and reciprocity, meanwhile poverty was measured by such livelihood status, poverty line, household income, household welfare and other poverty levels that rely on income and consumption comparison. The findings in this review support the general conclusion that social capital is statistically significant in reducing the poverty of households. More qualitative studies are recommended to be conducted due to several recommendations which are to have specific and a standard systematic review method for guide research synthesis in context social capital with poverty reduction. Other than that complementary searching techniques such as citation tracking, reference searching, snowballing and contacting experts are needed.
\end{abstract}

Keywords: Systematic Review; Social Capital, Poverty, Poverty reduction.

\section{Introduction}

Poverty usually occurs when a person is shackled by lack of resources. According to According to World Bank (2005), poverty is highly associated with lack of income and an individual can be considered poor if the level of his or her income drops under the minimum level of basic needs. For the last few decades, poverty reduction has become one of the priority topics in policy development where many countries have adopted the poverty line as a method to measure poverty. The Poverty Line Income (PLI) is used to sort the status of households into either nonpoor or poor. As revealed by the government, poverty can be defined as lack of financial ability to get the basic needs and this involves food and non-food components such as education, healthcare, clothing, transportation, house rental and also recreation (Siwar, Ahmed, Bashawir and Mia, 2016; EPU, 2002). However, using income as a measurement for poverty without involving other important dimensions like education, stable jobs, social security, healthcare, and savings is not sufficient in providing a complete picture on the issue discussed (Hussain, 2019).

In dealing with the issue and despite limited and scarce resources, many governments channel out resources to promote economic growth in their country. Unfortunately, the rate of poverty remains high in several states of the country (Siwar et al. 2016; EPU., 2009) despite of such intervention and such a situation will soon pejoratively affect the economy of a country (Siwar et al. 2016; Ali and Ahmad, 2009). For this reason, immediate and appropriate action are crucial to solve the poverty issue before it further escalates and creates unwarranted domino effects. Therefore, a study on how social capital can mitigate poverty is of paramount importance.

As stated earlier, there is a need to view poverty beyond income and that social capital is one of the important elements in the poverty reduction (Ismail, Mahfodz and Sulaiman, 2016). With that being said, social capital can be classified as a potential mechanism to reduce poverty. This claim is based on previous studies that have shown how social capital can improve the individual's and household's level of income in a country. By emphasizing on four types of measurement such as social cohesion, social participation, trust, and reciprocity and also a social network, social capital is expected to eradicate poverty and can promote positive well-being in Malaysia. However, studies on the association between social capital and eradication of poverty are still lacking in Malaysia. Hence, this study is of paramount importance since to date there is no collective systematic review discussion on social capital and poverty reduction.

The work in this study is relevant towards the appraisal of literature related to social capital and poverty reduction. The discussion highlighted in this work will guide policy makers and government to plan viable 
strategies to reduce and eradicate poverty. With an aim to focus on the association between social capital and poverty reduction, the next sections will present the methodology of the study. Then, the researchers will highlight the findings on systematic review of the selected articles before discussing the findings. Finally, conclusion is made to encapsulate the discussion.

\section{Methodology}

This section describes the methodology to retrieve and analyse the previous literature on the association of social capital to poverty reduction. Researchers utilize the PRISMA method to retrieve, review, abstract and analyse articles from ten (10) databases (Web of Science, Scopus, Science Direct, Taylor Francis, SpringerLink, SAGE, Emerald Insight, JStor, Oxford Journals and Wiley Online Library).

\section{PRISMA}

PRISMA Statement or also known as Preferred Reporting Items for Systematic reviews and Meta-Analyses was used as guidance throughout the systematic review (Bigonnesse et al., 2018). Through this method, rigorous search of literature related to the topic discussed can be done systematically.

\section{Resource}

Despite utilising 10 major databases, the reviews in this study depend greatly on two (2) main databases, i.e. Web of Science (WoS) and Scopus because they offer more comprehensive searching tools compared to other databases. Nevertheless, this study still utilises supplementary databases such as Science Direct, Taylor Francis, SpringerLink, SAGE, Emerald Insight, JStor, Oxford Journals and Wiley Online Library to cater all possible literature that is relevant for a comprehensive review.

\section{Eligibility and exclusion criteria}

This study applies viable eligibility criteria i.e. (i) retrieve only journal articles as they are more complete and they contain the more valid and trustworthy reports (Bar-Ilan, 2010; Montesi \& Mackenzie, 2008), and the case studies reflect contemporary phenomenon within the real-life context (Yin, 1994), (ii) only consider English publication to ease search and analysis of literature and (iii) only articles that focus on the association between poverty and social capital are retrieved. These criteria are presented in Table 1.

Table 1. Inclusion and exclusion criteria.

\begin{tabular}{|l|l|l|}
\hline Criterion & Eligibility & Exclusion \\
\hline Literature type & $\begin{array}{l}\text { Journal articles including case } \\
\text { studies }\end{array}$ & $\begin{array}{l}\text { Review articles, chapter in book, } \\
\text { conference proceeding }\end{array}$ \\
\hline Language & English & Non-English \\
\hline Focus of study & Poverty and Social capital & Non-Poverty/Non-social capital \\
\hline
\end{tabular}

\section{Systematic review criteria}

An integrative systematic review that caters articles using qualitative, quantitative and mixed methods, allows a rich overview of articles with multiple research approaches (Jackson, Davidson, Adams, Edordu \& Picton, 2019). The systematic review, that is based on 10 databases was performed on March 2020 and it involved four (4) stages. The process began with keyword identification for the searching process. Several keywords related to social capital and poverty were identified based on suggested keywords from previous studies on online databases like Scopus and Thesaurus. This study prioritises and customises certain words for specific search such as title, abstract or keyword sections. The search strings for different databases are as in Table 2.

Table 2. The search strings used for systematic literature reviewing

\begin{tabular}{|c|c|c|}
\hline Journal database & & \\
\hline Wos & TOPIC = (("social-capital") AND (relationship) AND (poverty)) & 189 \\
\hline Scopus & TITLE-ABS-KEY (("social capital") AND (relationship) AND (poverty)) & \\
\hline Science Direct & $\begin{array}{l}\text { ("social capital*") AND relationship AND (poverty OR poverties OR } \\
\text { poorness OR privation OR destitution) }\end{array}$ & 39 \\
\hline Taylor Francis & [Keywords: “social capital*”] AND [Keywords: povert*] & 36 \\
\hline SpringerLink & title $=$ social capital and relationship and poverty & 0 \\
\hline SAGE & $\begin{array}{l}\text { [Abstract "social capital*"] AND [Abstract relationship*] AND [Abstract } \\
\text { povert*] }\end{array}$ & 28 \\
\hline Emerald Insight & $\begin{array}{l}\text { [[Abstract: "social capital*”]] AND [[Abstract: relationship*]] AND } \\
\text { [[Abstract: povert*]] }\end{array}$ & 5 \\
\hline JStor & $(($ ab:(social-capital) AND ab:(relationship)) AND ab:(poverty)) & 11 \\
\hline Oxford Journals & [Keywords: "social capital*”] AND [Keywords: poverty*] & 3 \\
\hline Wiley Online Library & $\begin{array}{l}\text { "social capital*" in Abstract and relationship* in Abstract and poverty* } \\
\text { in Abstract }\end{array}$ & 31 \\
\hline
\end{tabular}

472 articles responded to the search strings on 10 databases. Six (6) redundant articles were removed during the identification stage. At the screening stage, the researcher rejected 436 articles while 20 more articles were 
excluded at eligibility stage. Finally, after going through a stringent process in identifying the suitable articles through this rigid systematic review that requires an extremely demanding process and time-consuming (Mallet, Hagen-Zanker, Slater \& Duvendack, 2012), only ten (10) articles were retained as they clearly focused on the theme of the study. The PRISMA flow diagram is illustrated in Figure 1.

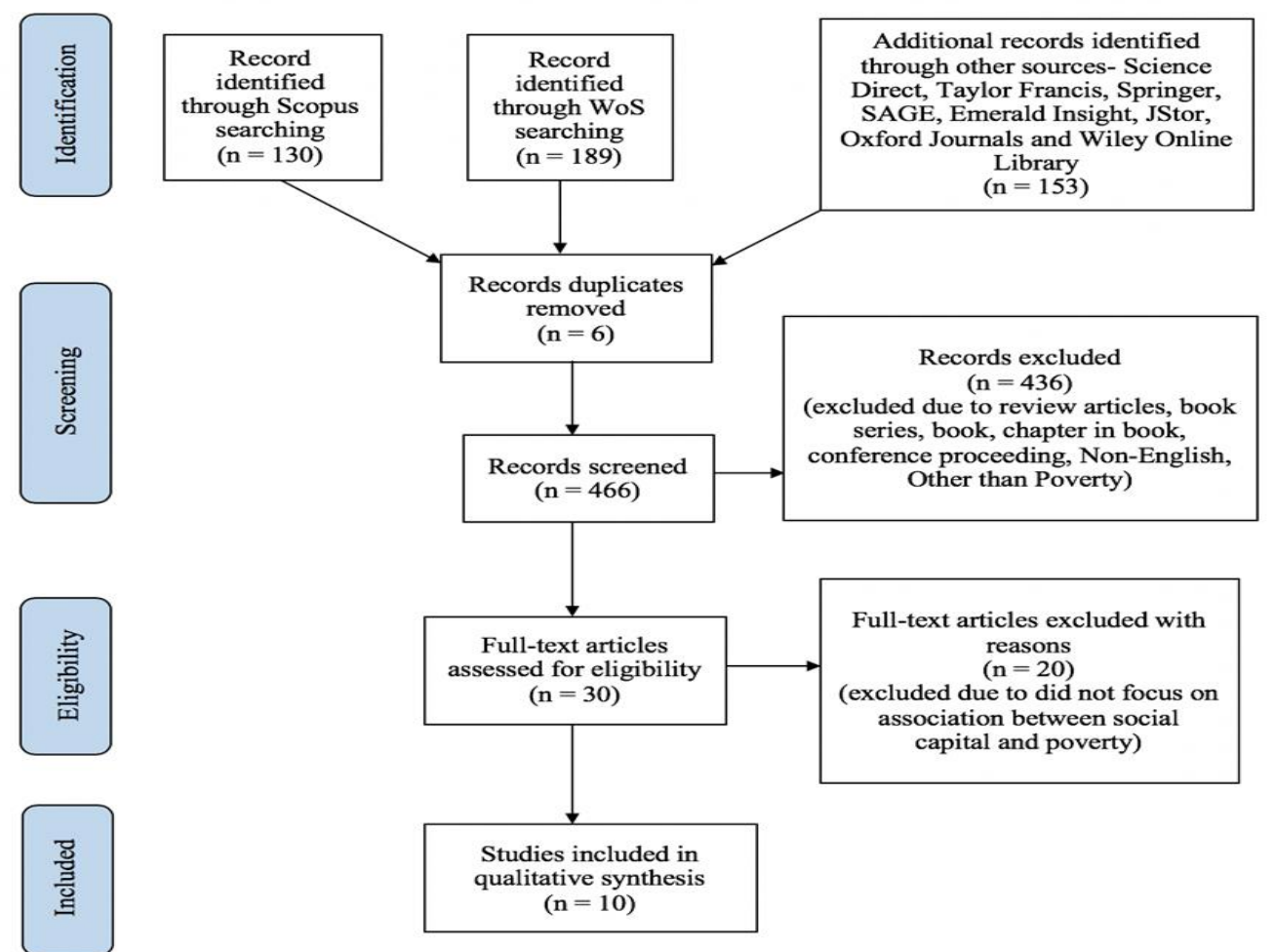

Source: Adapted from Moher, Liberati, Tetzlaff, and Altman (2009)

Figure 1. The flow diagram of the study.

Data abstraction and analysis

Ten (10) articles identified through PRISMA analysis were analysed. The analysis began by looking at the abstract then followed by the article content. Considering the aim and focus of the study, many of the analysed articles had led to varied outcomes (poverty) and different appraisals for social capital. This situation limited the researchers from implementing a meta-analysis, hence, the results were illustrated in narrative form. Three categories of association were revealed after summarizing and synthesising the result i.e. (1) results showing a negative association between social capital and poverty reduction, (2) positive association and (3) no association.

\section{Results}

This section presents findings through these themes: (i) study description; (ii) measure of social capital; (iii) measure of poverty; and (iv) association between social capital and poverty.

\section{Study Description}

Table 3 discusses the demographics and characteristics of the population extracted from the reviewed articles and Table 4 shows the paper title and research objectives of the ten reviewed articles. This study found that there were three articles had been conducted in the same context (China) while the remaining papers were conducted in different contexts respectively. Researchers were mostly interested in the household population compared to other populations. Yunus, Zainal, Jalil and Sari (2020), explored the correlation between social capital and poverty level among farmers from three districts in Aceh. The study involved 300 people as their sample size and it was identified that the poverty rate in Acheh, Indonesia was more than $40 \%$.

Another study by Islam and Alam (2018) assessed the relationship between social capital and poverty reduction with reference to Bangladeshi's context. By using questionnaires as a method for data gathering, almost 310 eligible persons were chosen as their sample size. The study which took place from 05 to 30 June 2014 had successfully received their questionnaires back from the heads of households in remote Bangladesh. The data were consisted of $66.5 \%$ male and $33.5 \%$ female household heads, while the average age for the household heads was 43.07.

Similarly, Baiyegunhi (2014) also investigated the relationship of households' social capital with poverty reduction. The study was participated by six community groups at University of KwaZulu-Natal in South Africa. The data conducted as part of a quantitative study that involved 300 rural households which included both gender male and female. 
Liu, Clem and Wang (2019) explored the importance of social networks, trust and mutual help, and also social norms which represent social capital towards poverty reduction in China in 2016. 120 respondents, which involved 51 poor households and 69 non-poor households, took part in this study. Kim, Lee and Choi (2014) examined the effect of social capital towards economic status of female immigrants who are married to the locals in South Korea. They used data from the 2009 National Survey of Multicultural Families in Korea. A good number of 69394 respondents had taken part in the study.

Zhang, Zhou and Lei (2017) assessed the relationship between social capital and poverty reduction which focuses on the household's probability. The study was conducted in China and used interviews in a qualitative study design. There were 25, 650 participants, consisted of male and female households in rural areas, participated in the study.

In tandem with other researchers, Liu, Huang, Wang, Shuai and Li (2020) showed their interest in examining the impacts of social capital on the poverty reduction in China. The study was conducted from April to September 2018 focusing on poor male and female households. There were 1112 samples involved in the study.

Furthermore, Johannes and Andrew (2016) conducted a study on social capital and households' poverty. The study examines the effect of social capital on households' poverty. By using the 2007 Cameroon's household survey, around 12,000 households were eligible to choose as respondents. Referring to the data, the average age of household heads was 43 years old and 26 percent were female. Moreover, around $15 \%$ of household heads worked in the formal sector.

Another study done by Robert (2012) involved 20,041 people as his respondents to assess the role of social capital, in terms of social trust and voting behaviour, on poverty reduction. The data were collected from February to November 2008, from 10 provinces in Canada. which aged at least 15 years old. Based on the data collected in Canada, 56.68 percent of the respondents were female and the balance 36.81 percent presenting participants ages 35-54 years old.

Sunil and Pradyot (2019) investigated the impact of the member in credit or savings, member in caste association, member in development or non-governmental organization and member in cooperative societies towards poverty in eastern rural India. The study investigated 1353 rural households which comprised of two surveys conducted from 2004 to 2005 and 2011 to 2012.

Table 3: Study Demographic and Characteristics

\begin{tabular}{|c|c|c|c|c|c|c|}
\hline Study ref & Setting & Study design & Population & Study date & Sample size & Gender \\
\hline $\begin{array}{l}\text { Yunus et al. } \\
2020\end{array}$ & $\begin{array}{l}\text { Acheh, } \\
\text { Indonesia }\end{array}$ & $\mathrm{Q}_{1}$ & Farmers & & 300 & $\begin{array}{l}\text { Female } \\
\text { and Male }\end{array}$ \\
\hline $\begin{array}{l}\text { Islam and } \\
\text { Alam, } 2018\end{array}$ & Bangladesh & $\mathrm{Q}_{1}$ & $\begin{array}{l}\text { Rural } \\
\text { Household }\end{array}$ & $\begin{array}{l}\text { 05-30 June } \\
2014\end{array}$ & 310 & $\begin{array}{l}\text { Female } \\
\text { and Male }\end{array}$ \\
\hline $\begin{array}{l}\text { Baiyegunhi, } \\
2014\end{array}$ & $\begin{array}{l}\text { South } \\
\text { Africa }\end{array}$ & $\mathrm{Q}_{1}$ & $\begin{array}{l}\text { Rural } \\
\text { households }\end{array}$ & & 300 & $\begin{array}{l}\text { Female } \\
\text { and Male }\end{array}$ \\
\hline Liu et al. 2019 & China & $\mathrm{Q}_{1}$ & Household & 2016 & 120 & $\begin{array}{l}\text { Female } \\
\text { and Male }\end{array}$ \\
\hline $\begin{array}{l}\text { Kim et al. } \\
2014\end{array}$ & $\begin{array}{l}\text { South } \\
\text { Korea }\end{array}$ & $\mathrm{Q}_{1}$ & $\begin{array}{l}\text { Female } \\
\text { immigrants }\end{array}$ & 2009 & 69,394 & Female \\
\hline $\begin{array}{l}\text { Zhang et al. } \\
2017\end{array}$ & China & $\mathrm{Q}_{1}$ & Households & & 25,650 & $\begin{array}{l}\text { Female } \\
\text { and Male }\end{array}$ \\
\hline
\end{tabular}




\begin{tabular}{|c|c|c|c|c|c|c|}
\hline Liu et al. 2020 & China & $\mathrm{Q}_{1}$ & $\begin{array}{l}\text { Poor } \\
\text { Household }\end{array}$ & $\begin{array}{l}\text { April- } \\
\text { September } \\
2018\end{array}$ & 1112 & $\begin{array}{l}\text { Female } \\
\text { and Male }\end{array}$ \\
\hline $\begin{array}{l}\text { Johannes and } \\
\text { Andrew } 2016\end{array}$ & $\begin{array}{l}\text { Cameroon, } \\
\text { Africa }\end{array}$ & $\mathrm{Q}_{1}$ & Households & 2007 & 12000 & $\begin{array}{l}\text { Female } \\
\text { and Male }\end{array}$ \\
\hline Robert 2012 & Canada & $\mathrm{Q}_{2}$ & Residents & $\begin{array}{l}\text { Feb - Nov } \\
2008\end{array}$ & 20,041 & $\begin{array}{l}\text { Female } \\
\text { and Male }\end{array}$ \\
\hline $\begin{array}{l}\text { Sunil and } \\
\text { Pradyot, } 2019\end{array}$ & India & $\mathrm{Q}_{1}$ & Households & $\begin{array}{l}2004-2005 \\
2011-2012\end{array}$ & 1353 & $\begin{array}{l}\text { Female } \\
\text { and Male }\end{array}$ \\
\hline
\end{tabular}

Q1 quantitative study, Q2 qualitative study

Table 4: Paper title with research objective

\begin{tabular}{lll}
\hline Study ref & Paper title & Objective \\
\hline
\end{tabular}

1 Yunus et al. $2020 \quad$ Correlation of Social Capital and Poverty Farmers in Acheh

2 Islam and Alam, 2018

3 Baiyegunhi, 2014

$4 \quad$ Liu et al. 2019

$5 \quad$ Kim et al. 2014

$6 \quad$ Zhang et al. 2017

$7 \quad$ Liu et al. 2020

8 Johannes and Andrew 2016
Does social capital reduce poverty? A cross-sectional study of rural household in Bangladesh

Social Capital Effects on Rural Household Poverty in Msinga, Kwazulu-Natal, South Africa

Poverty and its reduction in a Chinese border region: is social capital important?

Employment and Poverty Status of Female Marriage Immigrants in South Korea*

Social Capital and Its Contingent Value in Poverty Reduction: Evidence from Western China

Understanding the Role of Rural Poor's Endogenous Impetus in Poverty Reduction: Evidence from China

Does social capital really determine poverty? Evidence from a Cameroon household survey to examine the correlation between social capital and the poverty level of farmers in Aceh

to examine the relationship between social capital and poverty reduction with special reference to Bangladesh.

This study examined the relationship between rural households' social capital and poverty.

This article investigates the extent to which social capital (and other variables) are associated with the absence of poverty in such regions This study explores the economic status of female marriage immigrants in South Korea

In this paper we empirically investigate the relationship between social capital and households' probability of living under poverty.

examine the impact of social capital on their poverty reduction.

This paper examines the effect of social capital on household poverty using the 2007 Cameroon household survey 
$9 \quad$ Robert 2012

10 Sunil and Pradyot, 2019
Social capital and its role in poverty reduction: a Canadian-based analysis

Switch in Livelihood Strategies and Social Capital Have a Role to Play in Deciding Rural Poverty Dynamics: Evidence from Panel Data Analysis from Eastern India to estimate the associations between two social capital dimensions; that is, trust and voting behaviour, and economic well-being.

to examine the role of livelihood diversification and social capital in the movement of these households into and out of poverty in Eastern rural India.

\section{Measure of Social Capital}

This section extracted the measurements used to investigate social capital from ten articles reviewed. Table 5 below presents the summary of how social capital being measured based on the ten articles.

Table 5: Measure of Social Capital

\section{Study ref}

\begin{tabular}{llll}
\hline Trust and & Social & Social & Social \\
Reciprocity & Participation & Cohesion & Network
\end{tabular}

$1 \quad$ Yunus et al., 2020

2 Islam and Alam, 2018

3 Baiyegunhi, 2014

$\mathbf{X}$

$\mathbf{X}$

$4 \quad$ Liu et al., 2019

$5 \quad$ Kim et al., 2014

6 Zhang et al., 2017

$7 \quad$ Liu et al., 2020

8 Johannes and

Andrew, 2016

$9 \quad$ Robert, 2012

10 Sunil and Pradyot, 2019
X

$\mathbf{X}$

$\mathbf{X}$

X

$\mathbf{X}$

Social Capital

X

X

X

X $\quad$ X

X

X

X 
Based on the rigorous review done on the past literature in this study, the scopes of social capital were categorized into three domains and they are: relational (social participation and social cohesion), cognitive (trust and reciprocity) and structural (social network). social network appeared to be the most used measurement (seven out of the ten reviewed articles) for social capital effects in the articles reviewed.

Yunus et al. (2020) measured social cohesion as community social and collective action among farmers in Acheh. The non-poor farmers scored higher mean rank compared to poor farmers. More correlate collective action caused easier assistance from outside parties to the community which can reduce spending cost for each farmer family. On the other hand, Islam and Alam (2018) measured social cohesion as neighbourhood cohesion among rural households in Bangladesh. They proved that how neighbourhood can affect poverty using five dimensions. However, a study by Baiyegunhi (2014) interpreted social cohesion as empowerment and political action, collective action, and social cohesion. All of these three items were studied to identify the effects of social capital to the poverty among rural households in South Africa. Liu et al. (2019), on the other hand measured social cohesion as social norms among households in China. Two questions were asked to obtain information regarding this factor included of whether household participate in village activities and would they criticized or condemned those activities.

Since social capital can be measured by viable factors, therefore social participation, can also be classified as one of its measurements. By definition, social participation can be about how active a person is involved in the activities whether formal or informal. Islam and Alam (2018) employed social participation as civic participation where they found that less participation in the decision-making process, would drag rural households in Bangladesh into poverty. This is different than Zhang et al. (2017) who had chosen participation in a voluntary association as a yardstick to measure the effect of social participation towards poverty reduction. As mentioned by the authors, involving in an association was one of the crucial actions that will strengthen the connection inside the organization and empower higher knowledge and skills transfer within the community. Furthermore, Liu et al. (2020) used 'social exclusion and disrespect' to measure the effect of social capital on rural households' poverty in China. The results showed that social exclusion and disrespect will not improve the rate of poverty because the self-efficacy and aspirations of the poor had been reduced by the exclusion. On a different note, Sunil and Padyot (2019) measured social participation based on how active a person is. He measured this habit by looking at whether the household heads were a member of a credit or savings account, caste association, development/non-governmental organization, or cooperative society. The results showed that the probabilities of escaping poverty was increased by $10.1 \%$ and $7.4 \%$ respectively if the household heads are members of a savings group and a part of development or NGO groups.

Besides social cohesion and social participation, trust and reciprocity were also used as one of the social capital measurements. Yunus et al. (2020) measured trust and reciprocity as social capital among farmers in Acheh. The results classified that non-poor farmers had higher mean rank compared to poor farmers. In Islam and Alam (2018), trust and reciprocity were also used as a measurement for social capital. In their study, social trust and reciprocity was used to clarify the effect of social capital in rural households in Bangladesh. In fact, social trust might have significant economic impacts and at the same time will decrease poverty. Baiyegunhi (2014) explored social trust to understand the effect of social capital to rural households in South Africa. In his/her? study, social trust was measured by trusting and helping habits in the community. Similarly, Liu et al. (2019) also used trust and mutual help to measure social capital among households. They inferenced that higher trust can provide several benefits to the village especially when it comes to improving the efficiency of the households' supply. On the other hand, Robert (2012) explored social capital as social trust and voting behaviour. Social trust can be referred as the trust of neighbours, communities and also strangers that can upgrade the economic well-being of the residents.

Apart from previous dimensions, social network also plays a vital role in measuring social capital and seven from ten articles reviewed here were found to use social network as one of the social capital measurements. Yunus et al. (2020) employed social network as a measurement of poverty in Acheh. Social network can be classified in terms of support, advice, guidance, services, information or material resources that a person gets from other people. Similarly, Islam and Alam (2018) used social network and social support to measure social network among rural households in Bangladesh. As social network is one of the salient strategies to survive from their current state, this dimension will provide them with access to get help, information and resources from outsiders. Baiyegunhi (2014), on the other hand defined social network as a measurement for social capital. The study measures social network by determining the membership of the households and the ability to get support from other resources. Moreover, Liu et al. (2019) also used social networks to identify the effects of social capital on poverty in China. The more social network be spawned, the higher is the chance of households in China to escape from poverty. In Kim et al. (2014), social support was also used as an indicator of social capital. According to the aforementioned study, political and business connection can be one of the social network measurements. The results supported the idea that large social support will lessen the probability of becoming poor for immigrant women. In lieu of connection, Zhang et al. (2017) had used political and business connection to investigate the effects of social capital towards the poverty in China. Having both connections as households' social network was found to increase households' resources, knowledge and information regarding certain programs offered for their stakeholders. Johannes and Andrew (2016) measured social network as receiving help from family members, NGOs,, and religious institutions . The results highlighted that around 82 percent of households that join the association because of economic factor and 27 percent of them continue to take part due to having important responsibility in the group. 


\section{Measure of Poverty}

Across the ten articles reviewed in this study, poverty was defined as households' well-being with income and consumption of each household sat above the poverty line. There were viable measurements for poverty which include livelihood status, poverty line, household income, household welfare and poverty level and these measurements rely on income and consumption comparison. Yunus et al. (2020) measured poverty based on income dimension (poverty level). This income dimension can be used to identify whether a farmer is poor or nonpoor. This approach is different than the method suggested by Islam and Adam (2018) who measured poverty based on the poverty line through the Cost Basic Needs (CBN) method. People are considered poor if their per capita expenditure is below than the suggested poverty line. This means, the non-poor people's expenditure is above the poverty line. Similarly, Baiyegunhi (2014) also measured poverty in South Africa according to the poverty line. When the value of consumption for a household is below than the poverty line, that person is considered as poor. In contrast, Liu et al. (2019) used the income of households to define poverty. A household is considered as poor if the income is less than 2855 yuan.

Kim et al. (2014) also measured poverty by referring to household's income, organized in eight categories ordinally such as less than 500,000KRW, between 500,000 KRW and 999,999KRW and so on. Concurrently, Zhang et al. (2017) also measured poverty based on households' income. According to Chinese government, a household is considered in deprivation if their per capita income is less than 683 RMB yuan. However, Liu et al. (2020) referred poverty as households' livelihood status. Johannes and Andrew (2016) measured livelihood by looking at how well the households allocate their income to expenditure and consumption. In contrast, Robert (2012) utilised GSS ordinal-level variable to measure residents' personal income. Twelve (12) categories were used to measure the personal income, with twelve (12) indicating income $\$ 100,000$ or more and one (1) for no income. On the same note, Sunil and Pradyot (2019) utilised the poverty line that was defined by Indian Planning Commission. In conclusion, most of the studies used poverty line as their measurement of poverty.

\section{Association between Social Capital and Poverty}

Yunus et al. (2020) provided some insights into the issues of poverty among farmers in Acheh, Indonesia. Social cohesion as measured by community social and collective action significantly affect $(B=0.187, p=0.001)$ the farmers' poverty in Acheh. Similarly, Yunus et al. (2020) andBayegunhi (2014) also found that empowerment and political action, collective action and, social cohesion were significantly associated with households's poverty in South Africa ( $\beta=-0.859, p=0.001)$. However, a study by Islam and Alam (2018) contradicted the past studies where their results showed that neighborhood cohesion heralds no significant association in rural households in Bangladesh. On a similar note Liu et al.'s (2019) study also did not achieve the expected result when not significant association can be found between social norms and poverty reduction among households in China.

As for another measurement of social capital, that is social participation, it is expected to significantly associate with poverty. Fortunately, all articles in this study that used social participation as a measurement of social capital, showed significant association to poverty. Islam and Alam (2018) employed civic participation to measure social capital and it was found thatsocial capital is significantly associated to rural households' poverty reduction in Bangladesh $(\mathrm{OR}=0.783, \mathrm{p}<0.1)$. This finding is in congruence with, Zhang et al (2017) and Sunil and Padyot (2019) when both studies found that social participation is significantly associated with the poverty reduction. Liu et al. (2020), however, found that social participation was not significantly associated to poverty with reference to its direct effect $(\mathrm{T}=0.398, \mathrm{p}=0.691)$. While fully mediation when mediator is adding to that relationship of social participation and poverty.

Unfortunately, by referring to the five articles that used trust and reciprocity as measurements for social capital, this study found inconsistency on the association. Liu et al. (2019), was the only article that shows no relationship between trust and poverty. They pointed out that trust and mutual help were not significantly associated to the probability of a household not being poor $(\beta=1.47, \mathrm{p}=0.16)$. By measuring social capital through social trust, Yunus et al. (2020) indicated that there was a positive and significant relationship between social capital and poverty level among Acheh farmers. This showed that having higher stock of social capital can reduce the poverty rate of farmers. Islam and Alam (2018), through binary logistic regression, had shown that increasing norms of reciprocity was significantly associated with the rural household's poverty in Bangladesh $(\mathrm{OR}=0.488, \mathrm{p}<0.001)$. Besides that, Baiyegunhi (2014) also revealed that the effect of trust and help through social capital towards poverty was negative and significant $(\beta=-0.859, \mathrm{p}=0.001)$ in the rural households in South Africa. In a study done on the effects of social trust on voting behaviour towards economic well-being, Robert (2012) found that social capital was positively associated with economic well-being $(\beta=0.119$, $\mathrm{p}<0.001)$.

From the perspectives of social network, it was found that there was a significant association between social capital and poverty reduction in seven articles reviewed in this study. Yunus et al. (2020) for example revealed that support, advices, guidance, services, information and material resources were significantly associated with the poverty of farmers in Acheh $(\beta=0.123, p=0.034)$. Similarly, Islam and Alam (2018) also indicated that social network significantly affected the poverty in Bangladesh $(\mathrm{OR}=0.709, \mathrm{p}<0.05)$. Such a situation indicates that that higher a social network is, the more probability for the households to escape poverty. Bayegunhi (2014), through logistic regression model, showed that social network especially social capital is associated with poverty ( $B=-$ 
0,859, $\mathrm{p}=0.001$ ). Moreover, as found by Liu et al. (2019), social network significantly affected the poverty reduction among households in China $(\beta=2.56, p=0.01)$. This also indicates that, maximizing the social network will increase the probability of households to escape from poverty. In Kim et al. (2014), lack of social support significantly affected the probability of immigrant women to become poor $(\beta=-0.14, p<0.05)$. The study indicated that increasing social support was one of the strategies to reduce the poverty among immigrant's women in South Korea. Being in tandem with Kim et al. (2014), Zhang et al. (2017) also found that social networks such as political and business connection were statistically significant with poverty reduction. Finally, viewing social capital as receiving help from family, NGOs, religious institutions and others was found to be legit as Johannes and Andrew (2016) found social capital to be positively associated with economic well-being.

To sum, through the articles reviewed in this study, social capital constructs were evaluated for two times against the poverty indicators. Most of the time, the results highlight positive significant between the variables and only two situations where the association was found negative. By comparing the four measurements for social capital as well, it is found that only social participation and social network remained their significant relationship with poverty.

\section{Discussion}

This review tries to investigate and assess the connection between social capital and poverty reduction. The systematic review in this study suggests that social capital can significantly predict poverty reduction. Concurrently, there is also viable association across measurements, countries and sample sizes. Table 6 below shows the association between poverty and social capital measurements.

Table 6: Association between poverty and social capital measures

\begin{tabular}{|c|c|c|c|c|c|c|}
\hline & \multirow[t]{2}{*}{ Study ref } & \multicolumn{4}{|c|}{ Social Capital } & \multirow{2}{*}{$\begin{array}{c}\text { Analysis } \\
\text { Type }\end{array}$} \\
\hline & & $\begin{array}{l}\text { Trust and } \\
\text { Reciprocity }\end{array}$ & $\begin{array}{l}\text { Social } \\
\text { Participation }\end{array}$ & $\begin{array}{l}\text { Social } \\
\text { Cohesion }\end{array}$ & $\begin{array}{l}\text { Social } \\
\text { Network }\end{array}$ & \\
\hline 1 & Yunus et al. 2020 & $\begin{array}{l}\beta=0.122, \\
(p=0.035)\end{array}$ & & $\begin{array}{l}\beta=0.187, \\
(p=0.001)\end{array}$ & $\begin{array}{l}\beta=0.123, \\
(p=0.034)\end{array}$ & $\begin{array}{c}\text { Spearman } \\
\text { Correlation } \\
\text { using SPSS }\end{array}$ \\
\hline 2 & $\begin{array}{l}\text { Islam and Alam, } \\
2018\end{array}$ & $\begin{array}{l}\mathrm{OR}=0.488, \\
(\mathrm{p}<0.001)\end{array}$ & $\begin{array}{c}\mathrm{OR}=0.783 \\
\quad(\mathrm{p}<0.1)\end{array}$ & Not significant & $\begin{array}{c}\mathrm{OR}=0.709, \\
(\mathrm{p}<0.05)\end{array}$ & $\begin{array}{c}\text { Binary } \\
\text { Logistic } \\
\text { Regression }\end{array}$ \\
\hline 3 & $\begin{array}{l}\text { Baiyegunhi, } \\
2014\end{array}$ & $\begin{array}{l}\beta=-0.859, \\
(p=0.001)\end{array}$ & & $\begin{array}{c}B=-0.859, \\
(p=0.001)\end{array}$ & $(\mathrm{p}=0.001)$ & $\begin{array}{c}\text { Logistic } \\
\text { Regression } \\
\text { Model }\end{array}$ \\
\hline 4 & Liu et al. 2019 & $\begin{array}{c}\text { Not } \\
\text { significant } \\
(\mathrm{p}=0.16)\end{array}$ & & $\begin{array}{l}\text { Not significant } \\
\qquad(p=0.18)\end{array}$ & $\begin{array}{l}\beta=2.56, \\
(p=0.01)\end{array}$ & $\begin{array}{c}\text { Binary } \\
\text { Logistic } \\
\text { Regression }\end{array}$ \\
\hline 5 & Kim et al. 2014 & & & & $\begin{array}{c}\beta=-0.14, \\
(p<0.05)\end{array}$ & $\begin{array}{c}\text { Logistic } \\
\text { Regression }\end{array}$ \\
\hline
\end{tabular}


6

Zhang et al. 2017

Liu et al. 2020

Johannes and

Andrew 2016

Robert 2012

$\beta=0.119$,

Direct effect:

$\mathrm{T}=0.398$,

$(\mathrm{p}=0.691)$

Indirect

effect:

Fully

mediation

$\mathrm{T}=4.77$,

$(\mathrm{p}<0.001)$

10 Sunil and

Pradyot, 2019 $b=0.043$,

Propensity

Score

Matching

$(\mathrm{p}<0.001)$

Structural

Equation

Model (SEM)
Multivariate analysis $\beta=-0.146$,

$(\mathrm{p}<0.001)$
Multinomial

Logistic

Regression

\footnotetext{
Yunus et al. (2020) provided pertinentpertinentperception through their study where they interpreted the effects of social cohesion among farmers in Acheh towards poverty. Since majority of the reviewed articles focused on the households, the study by Yunus et al. (2020) played a contra action where it concluded that social cohesion can become a potential channel for farmers to reduce the poverty level among them. Similarly, other studies on social cohesion had shown that empowerment, political action, and collective action as a significant factor to the association between poverty and social cohesion (Bayegunhi, 2014). In contrast, Islam and Alam (2018) in a study that they conducted among 310 rural households in Bangladesh found that social cohesion did not show significant changes towards poverty. Moreover, Liu et al. (2019) also revealed the same situation when social norms among households in China could not be significantly associated to poverty. The inconsistency of the findings indicated that the effects of social cohesion were viable and may not be universal due to the different groups or country.

Given the aforementioned situations, all four studies that investigated the association between social participation and poverty revealed that social participation was significantly affected poverty reduction. As the level of social participations increased, there will be more chances for a person to get involved and influence decision making at local government or organizations (Islam and Alam, 2018). This finding was also coherent with a study by Zhang et al. (2017), Sunil and Padyot (2019), and Liu et al. (2020) where all the articles found that social participation was significantly associated with the poverty reduction. Indeed, households need to involve actively in social activities whether formal or informal, in order to get more access to escape from poverty.
} 
Despite indicating that all studies in this paper had concluded that social participation is of prominent importance in reducing poverty, trust and reciprocity however gave a conflicting result. There were contradictory findings between five related articles where one of the articles showed there was no significant effect between trust and reciprocity towards poverty. Liu et al. (2019) revealed that trust and help cannot simply reduce the probability of households being poor in China. On a different note, Yunus et al. (2020) in a study that they conducted among 300 farmers in Acheh found that trust and reciprocity show significant relationship towards poverty. Islam and Alam (2018) shared a similar view with Yunus et al. (2020) on this matter when they found that norms of reciprocity affect poverty among households in Bangladesh. Furthermore, two studies by Baiyegunhi (2014) and Robert (2012) also revealed the same results where trust and reciprocity affect the poverty among rural households in Africa and Canada. Even though four out of five research showed significant relationship towards poverty, government must also consider the non-significant parts. The finding suggests that government or people in the community should maximize their availability for the poor people by planning various occasions that can provide them with better access to improve their current state of living.

Besides that, the systematic review in this study reveals that the social network affects the poverty. Yunus et al. (2020) found that social networks gave a vital affect towards poverty reduction among farmers in Acheh. Similarly, in Bangladesh, social network is found to be one of the strategies to reduce poverty (Islam and Alam, 2018). Another study that shared the same results with Yunus et al. (2020) and Islam and Alam (2018) is the one by Baiyegunhi (2014) where he proved that social networks provide significant effects towards poverty reduction in South Africa. Similarly, a study among 120 households in China had identified that social network can increase the probability for households to escape poverty (Liu et al., 2019). Furthermore, a study by Kim et al. (2014) also indicated that social networks among female immigrants also provided significant effects to poverty reduction. Sharing the same results, Zhang et al. (2017) and Johannes and Andrew (2016) reveals that social networks were statistically significant with the poverty reduction in China and Africa. Given such conditions, it appears that improving the social network among households, could reduce the poverty probability. Indeed, it is crucial to improve poverty and welfare of rural households, therefore, some alternatives need to be taken by private sectors and policy makers to produce poverty reduction channels which contain better understanding towards the nature of poverty.

\section{Conclusion}

This study emphasises on the effects of social capital towards the poverty reduction in different countries. By focusing social capital in terms of social cohesion, social participation, trust and reciprocity and social network, the authority involved can maximize household's income, resident's income and economic well-being and subsequently reduce poverty.

\section{Acknowledgments}

The authors would like to thank the Ministry of Education (MOE) for funding this research. The support given by MOE under the Fundamental Research Grant Scheme (FRGS/1/2019/SS06/UTHM/03/3) for providing the facilities to perform this research is highly appreciated.

\section{References}

1. Ali, H. and Ahmad, S. (2009). Why poor regions remains poor? Evidence from Malaysia. Int. Rev. Bus. Res. Pap, 5, 340-351.

2. Baiyegunhi, L.J.S. (2014). Social capital effects on rural household poverty in Msinga, Kwazulu-Natal, South Africa. Agricultural Economics Association of South Africa, 53(2), 47-64. DOI: 10.1080/03031853.2014.915478.

3. Bigonnesse, C., Mahmood, A., Chaudhury, H., Mortenson, W. B., Miller, W. C., Martin, G. and Kathleen A. (2018). The role of neighbourhood physical environment on mobility and social participation among people using mobility assistive technology. Disability \& Society, 33(6), 866-893.

4. Department of statistics Malaysia (2013). The household income survey 2012. Retrieved from https:/www.dosm.gov.my/v1/index.php?r=column/cthemeByCat"\&cat=120\&bul_id=d1Flak9XZklSMI VqZkhoZUloZytYQT09\&menu_id=amVoWU54U54UTI0a21NWmdhMjFMMWcyZz09

5. EPU., 2002. Malaysia quality of life 2002. The Report Published by the Economic Planning Unit, Prime Minister's Department, Putrajaya, Malaysia, pp:15.

6. EPU., 2009. Ninth Malaysian plan 2006-2010. Economic Planning Unit, Prime Minister's Department, Putrajaya, Malaysia, pp:1-547.

7. EPU., 2012. Socio-economic statistics-household income and poverty. Economic Planning Unit, Prime Minister's Department, Putrajaya, Malaysia.

8. EPU., 2013. The Malaysian economy in figures 2013. Economic Planning Unit, Prime

9. Minister's Department, Putrajaya, Malaysia, pp: 35. http://

10. www.epu.gov.my/documents/10124/2257e64f-b08d-41b7-bed0-b6e6498c38a3.

11. Hussain, N. (2019, October 21). What's the Truth about Malaysian Poverty?. The Star.

12. Retrieved from https://www.thestar.com.my/news/nation/2019/10/21/what039s-the-truth-aboutmalaysian-poverty--newsflash. 
13. Islam, M.S. and Alam, K. (2018). Does social capital reduce poverty? A cross-sectional study of rural households in Bangladesh. International Journal of Social Economics. https://doi.org/10.1108/IJSE-072017-0295.

14. Ismail, R., Mahfodz, N.D. and Sulaiman, N. (2016). Level determinants of social capital index in Malaysia. Kajian Malaysia, 34(2), 101-121.

15. Jackson, D., Davison, I., Adams, R., Edordu, A., and Picton, A. 2019. "A systematic review of supervisory relationships in general practitioner training." Medical Education, 53: 874-885.

16. Johannes, T.A. and Andrew, W.V. (2016). Does social capital really determine poverty? Evidence from Cameroon households survey. African Journal of Science, Technology, Innovation and Development, 8(1). DOI:10.1080/20421338.2015.1128038.

17. Kim, H., Lee, S.Y. and Choi, I.H. (2014). Employment and poverty status of female marriage immigrants in South Korea. Asian and Pacific Migration Journal, 23(2), 129-154.

18. Liu, H., Clem, T. and Wang, F. (2019). Poverty and its reduction in a Chinese border region:Is social capital important?. Journal of Asia Pacific Economy, 1-23. DOI: 10.1080/13547860.2019.1591743.

19. Liu, J., Huang, F., Wang, Z., Shuai, C. and Li, J. (2020). Understanding the role of rural poor's endogenous impetus in poverty reduction: Evidence from China. Sustainability,12(2487), 1-16.

20. Mallett, R., Hagen-Zanker, J., Slater, R. and Duvendack, M. 2012. "The benefits and challenges of using systematic reviews in international development research." Journal of Development Effectiveness, 4(3): 445-455.

21. Moher, D., Liberati, A., Tetzlaff, J., and Altman, D. G. 2009. "Preferred reporting items for systematic reviews and meta-analyses: the PRISMA statement." PLoS Medicine, 6(7), e1000097. https://doi.org/10.1371/journal.pmed.100009.

22. Robert, D.W. (2012). Social capital and its role in poverty reduction: A Canadian-based

23. analysis. Journal of Comparative Social Welfare, 28(1), 57-74. DOI:

24. 10.1080/17486831.2012.636257.

25. Siwar, C., Ahmed, F., Bashawir, A. and Mia, M.S. (2016). Urbanization and urban poverty in Malaysia: Consequences and vulnerability. J. Applied Sci., 16, 154-160.

26. Sunil K. and Pradyot, R.J. (2019). Switch in livelihood strategies and social capital have a role to play in deciding rural poverty dynamics: Evidence from Panel Data Analysis from Eastern India. Journal of Asian and African Studies, 1(19). DOI: 10.1177/0021909619868243.

27. World Bank, 2005. Overview: Understanding measuring and overcoming poverty. http://www.colorado.edu/philosophy/healthwood/pdf/worldbank.pdf.

28. Yunus, S., Zainal, S., Jalil, F. and Sari, C.M.A. (2020). Correlation of social capital and poverty farmers in Acheh. Human \& Social Sciences Reviews, 8(1), 20-26.

29. Zhang, Y., Zhou, X. and Lei, W. (2017). Social capital and its contingent value in poverty

30. reduction: evidence from Western China. World Development, 1-12.

31. http://dx.doi.org/10.1016/j.worlddev.2016.12.034. 